Topik: Budaya Kekerasan

\title{
Aparat Hukum dan Pembenaran Kekerasan
}

\author{
Rusli Muhammad
}

The law apparatus for instance police, attorney and judge (jurist) are not only as an important pillar in state but also become an element in the criminal court system. The running well system of formal procedure, but sometimes faces the critical condition that implies to conduct violence either individually or collectively that direct to hard and soft violence. The violence action that conducted by law apparatus can not separate from and closed relation to their professional experiences, the principles of inquisitoir, crime model control and formal decision either national or international.

Kata kunci: kekerasan, aparat, fisik, hukum, dan peradilan.

$\square$ ara pendiri negeri ini telah menyepakati bahwa Negara Republik Indoneisa adalah berbentuknegara hukumyang bertujuan melindungi segenap bangsa dan seluruh tumpah darah Indonesia, memajukan kesejahteraan umum, mencerdaskan kehidupan masyarakatdan ikut melaksanakan ketertiban dunia yang berdasarkan kemerdekaan, perdamaian abadi dan keadilan sosial. Sebagai konsekuensi adanya tujuan dan pilihan terhadap bentuk negara hukum seperti itu, menghendaki adanya kehanusan dipenuhinya alat-alat periengkapan negara untuk mengaktualisasikan tujuan dan bentuk negara tersebut. Di antara alat-alat perlengkapan yang dimaksud, salah satunya adalah apa yang dikenal dengan istilah "Aparatur Hukum" .
Aparatur hukum dalam sebuah negara hukum yang terkadang pula lebih populer dengan nama "Penegak Hukum" adalah menjadi tumpuan harapan bagi masyarakat dan negara agar hukum yang menjadi landasan dalam seluruh aktivitas kemasyarakatan dan kenegaraan benar-benar dapat diaktualisasikan dalam kehidupan nyata. Aparatur Hukum atau para penegak hukum menjadi penentu bagaimana eksistensi dan gambaran keberadaan dari sebuah negara yang berlandaskan hukum. Ketika segenap aparatur hukum dalam segala aktivitasnya senantiasa berlandaskan pada aturan hukum, maka gambaran sebuah negara hukum benarbenar menjadi sebuah kenyataan. Namun sebaliknya, jika para penegak hukum dalam menjalankan segala aktivitasnya menyimpang dari landasan hukum, maka eksistensi dari sebuah negara hukum menjadi sima dan yang tersisa tinggal simbul belaka. 
Kehadiran Aparatur. Hukum tidak dapat... tujuan tersebut menjadi tujuan bersama dan dihindari, adalah suatu keharusan karena menjadi salah.satu pilar terpenting dalam tatanan kehidupan bernegara. Kehadirannya tidak sekédar berfungsi untuk meiengkapi sarana-sarana kenegaraan, melainkan mengemban tugas yang berat karena pada dirinyalah hukum yang berintikan keadilan dapat ditegakkan, ditangannyalah berbägai konflik kepentingan baik perseorangan maupun kelompok dapat diselesaikan dan ditangannya pulalah pengendalian "sosial dapat dilaksanakan:

Untuk mendapatkan jaminan dalam menjalankan berbagai aktivitasnya, undangundang telah menentukan batasan dan berbagai kewenangan. Aparatur hukum menurut batasan undang-undang adalah mereka yang berkecimpung dan bergerak $\mathrm{di}$ lembaga kepolisian, kejaksaan kehakiman dan kepengacaraan, mereka tersebut adalah polisi, jakșa, hakim dan advokat. Masingmasing aparatur hukum tersebut, tugas dan wewenangnya diatur secara tersendiri dalam undang-undang. Undang-undang Nomor 28 Tahun 1997 Tentang kepolisian, Undangundang Nomor 16 Tahun 2004 Tentang Kejaksaan, Undang-undang Nomor 4 Tànun 2004 Tentang Kehakiman dan Undangundang Nomor 18 .Tahun 2003 Tentang Advokat. Melalui undang-undang inilah mereka mendapatkan jaminan dan kewenangan untuk menjalankan tugas dan kewajiban másing-masing.

Meskipun secara kelembagaan para aparatur hukum terpisah satu dengan lainnya, akan tetapi dalam menjalankan peran, khususnya peran dalam pengendalian kejahatan, mereka bekerja secara sistemik dan berada daiam satu sistem yang dikenal dengan sistem peradilan pidana. ${ }^{1}$ Masingmasing menjadi bagian dari sistem dan bekerja dalam ranigkaian sistem tersebut. Jika sistem tersebut memiliki tujuan, maka masing-masing harus bekerja.dalam rangka mencapai tujuan itu. Salah satu dari aparatur hukum melakukan penyimpangan dari tujuan bersama akan mempengaruhi kinerja aparatur lainnya yang berakibat semiakin sulitnya mencapai tujuan bersama itu. Óiéh karena itu kesadaran yang tinggi dalam memahami dan melaksanakan fungsi masing-masing serta tujuan bersama suatu sistem, sangat diperlukan dan tetap dịpelihara dengan baik.

Undang-undang sebagai sarana vital dalam suatu negara hukum; selain menjadi landasan dan pedoman bagi aparatur hukum dalam menjalankan aktivitasnya, dapat pula menjadi sarana sekaligus sebagai obyék yang harus diperjuangkan dan diüpayakan terus-menerus sehingga rumusan-rumusan yang sifatnya abstrak serta cita-cita yang terkandung didalamnya dapat terimplementasikan dalam kehidupan yang nyata, mengantarkan pada kehidupan aman, sejahtera dan berperadaban. Untuk itu, undang-undang atau peraturan dalam bentuk apapun, disusun dan dibentuk dengan memperhatikan dan mempertimbangkan syarat keberlakuannya yakni keberlakuan secara filosofis, yuridis dan soșiologis, ${ }^{2}$ terhindar dari interes-interes individual dan kelompok yang dapat menimbulkan ketidak nyamanan menjurus pada kẹbencian, permusuhan dan pertikaian.

1 Sistem Peradilan Pidana (Criminal Justice System) adalah suatu jaringan peradilan yang bekerja sama secara terpadu di antara bagian-bagiannya untuk mencápai tujuan tertentu baik jangka pendek maupun jangka panjang. Bagian-bagian dari sistem peradilan pidana itu yang dimaksudkan adalah terdiri dari kepolisiaan, kejaksaan, pengadilan dan lembaga. pemasyarakatan.

2 Keberlakuan hukum secara filosofis artinya sesuai dengan cita-cita hukum sebagai 
Aparatur hukum memfungsikan dirinya dalam berbagai aktivitas yang terakumulasi dalam rangkaian kegiatan penegakan hukum terkadang dihadapkan pada suasana yang tidak nyaman. Aparatur penegak hukum tidak selamanya mulus di dalam mengemban tugas kewajibannya, terkadang dihadapkan pada pilihan yang sangat sulit karena harus memilih tindakan yang tidak populer yang terkadang berdampak munculnya kerugian dan bahkan penderitaan pada orang lain. Kekerasan sebagai suatu fenomena di masyarakat adalah bentuk-bentuk tindakan yang tidak populer dan pasti mendatangkan berbagai kerugian dan penderitaan, namun terkadang menjadi pilihan aparatur hukum yang tidak terhindarkan.

Apakah kekerasan yang menjadi pilihan alternatif bagi aparatur penegak hukum dapat ditolerir dalam serangkaian usaha penanggulangan kejahatan sebagai bagian dari proses penegakan hukum ? jika ya, modusnya bagaimana dan seberapa jauh hal itu dapat dibenarkan. Persoalan inilah yang akan dicoba dibahas dalam tulisan ini.Namun sebelum sampai ke masalah itu, terlebih dahulu tulisan ini akan menguraikan bagaimana bekerjanya para aparatur penegak hukum dalam sistem peradilan pidana.

\section{Bekerjanya Aparatur Hukum dalam Sistem Peradilan}

Bekerjanya aparatur hukum dimaksudkan adalah serangkaian tindakan yang dilakukan oleh aparat hukum (polisi, jaksa penuntut umum, hakim dan petugas LP), dalam kaitannya dengan penyelesaian perkara pidana. Tindakann ini dimulai.ketika adanya informasi-informasi tentang adanya dugaan, akan, sedang atau telah terjadinya tindak pidana. Pertama-tama akan diawali dengan tindakan polisi dalam menghadapi tindak pidana. Polisi dalam hal ini dapat bertindak sebagai penyelidik dan penyidik.

Polisi mulai melakukan aktivitasnya berkaitan dengan tindak pidana, manakala telah menerima laporan atau pengaduan dari masyarakat. Dengan laporan dan pengaduan itu segera melakukan tindakan penyelidikan untuk mengetahui bahwa apakah benar-benar telah terjadi suatu perbuatan pidana atau tidak Hasil penyelidikan inilah kemudian dapat ditentukan apakah akan diteruskan pada tindakan penyidikan. Polisi dalam melakukan penyidikan pertama kali yang dilakukan adalah melakukan tindakan pertama di tempat kejadian. ${ }^{3}$ Namun tidak setiap tindak pidana yang tejadi , Polisi melakukan pemeriksaan di tempat kejadian, pemeriksaan ini hanyalah untuk tindak pidana yang berskala besar dan mendapat

nilai positif yang tinggi. Berlaku secara yuridis apabila penentiannya didasarkan pada kaedah yang lebih tinggi atau apabila terbentuknya menunut cara yang telah ditetapkan, atau apabila menunjukkan hubungan keharusan antara suatu kondisi dan akibatnya. Sedang berlaku secara sosiologis artinya apabila hukum tersebut berlaku karena diterima dan diakui oleh masyarakat.(Lihat Soerjono Soekanto dan Mustafa Abdullah dalam "Sosiologi Hukum dalam masyarakat" 1980. halaman 13).

3 PAF. Lamintang, dalam bukunya memberikan penjelasan bahwa yang dimaksud dengan "melakukan tindakan pertama di tempat kejadian" itu adalah melakukan segala macam tindakan yang oleh penyidik telah dipandang perlu utuk menyelamatkan nyawa korban atau harta kekayaan orang, menangkap pelakunya apabila pelaku tersebut masih berada dalam jangkauan penyidik untuk segera ditangkap dst.., Lihat Lamintang dalam "Kitab Undang-Undang Hukum Acara Pidana Dengan Pembahasan Secara Yuridis Menurut Yurisprudensi dan Ilmu Pengetahuan Hukum Pidana. Bandung: Penerbit Sinar Baru, 1984 him 76 
perhatian umum; untuk tindak pidana ringan hal tersebut tidak diperlukan.

Langkah selanjutnya yang dilakukan setelah melakukan pemeriksaan di tempat kejadian, polisi segera melakukan pemanggilan tèrhadap para saksi dan tersangka untuk dimintai keterangannya. Setiap pemeriksaan terhadap saksi dan terdakwa harus dibuatkan berita acaranya. Berdasarkan hasil pemeriksaan terhadap saksi dan tersangka, dilanjutkan kemudian dengan melakukan tindakan paksa berupa penangkapan, penahanan, penggeledahan dan penyitaan. Kesemua tindakan paksa ini harus dibuatkan pula berita acaranya masing-masing yang nantinya akan dihimpun ke dalam Berita Acara Pemeriksaan (BAP). Dengan disusunnya BAP oleh penyidik.kemudian diserahkan kepada. kejaksaan dan kejaksaan tidak mengembalikan lagi kepadanya berarti kerja polisi telah berakhir.

Berakhirnya kerja polisi menunjukkan awal akan dimulainya bekerjanya pihak Jaksa Penuntut Umum (JPU). Bekerjanya JPU dalam kaitannya dengan peradilan pidana tidak lepas dari bahan-bahan yang disam-paikan oleh pihak polisi. Melalui bahan-bahan itulah, JPU dapat melaksanakan tugas kewajibannya. Setelah menerima BAP hasil penyidikan yang disampaikan oleh penyidik, JPU segera mempelajari dan menelitinya dan dalam waktu 7 hari wajib memberitahukan kepada penyidik apakah hasil penyidikan itu sudah lengkap atau belum. Namun jika hasil penyidikan ternyata belum lengkap, penuntut umum mengembalikan berkas perkara kepada penyidik disertai petunjuk tentang hal yang harus dilakukan untuk dilengkapi.

Tindakan yang dilakukan oleh JPU tersebut di atas merupakan wujud dari apa yang disebut dengan "prapenuntutan". ${ }^{4}$ Jika berkas-perkara dinyatakan telah lengkap, JPU kemudian membuat surat dakwaan yang bahan-bahannya dirumuskan dari berkas yang diajukan oleh penyidik untuk kemudian dilanjutkan dengan melakukan penuntutan Pasal 1 angka 7 KUHAP memberikan pengertian tentang penuntutan. yaitu tindakan penuntut umum untuk melimpahkan perkara pidana ke pengadilan negeri yang berwenang dalam hal dan menurut cara yang diatur dalam undangundang ini dengan permintaan supaya diperiksa dan diputus oleh hakim di sidang pengadilan.

Adanyapelimpahan perkarake pengadilan atau penuntutan itu mengharuskan pengadilan melakukan serangkaian kegiatan yang keseluruhannya menjadi tanggung jawab hakim. Hakim pada pengadilan menjadi tokoh sentral karena di tangannyalah kekuasaan untuk mengadili dan memutus perkara yang diahadapkan kepadanya. Bekerjanya hakim diawali dengan diserahkannya berkas perkara yang telah ditetapkan oleh ketua pengadilan negeri. Hakim yang menerima berkas perkara dariketua pengadilan kemudian menyusun dan melaksanakan serangkaian kegiataan berdasarkan asas bebas, jujur dan tidak memihak menurut cara yang diatur oleh undang-undang.

Langkah pertama yang dilakukan oleh hakim adalah menentukan hari dan tanggal persidangan, diteruskan dengan perintah

4 Definisi tentang "prapenuntutan tdak disebutkan oleh KUHAP. Penulis mengartikan prapenuntutan adalah Tindakan jaksa penuntut umum untuk memeriksa dan meneliti kembali keseluruhan berkas perkara yang disampaikan oleh penyidik termasuk tindakan mempersiapkan surat dakwaan sebagai persiapan dan kelengkapan jaksa penutut umum sebelum melakukan penuntutan perkara ke sidang pengadilan. (Lihat : Rusli Muhammad; "Modul 'Hukum Acara Pidana. 2005 hal. 68). 
kepada JPU untuk segera melakukan pemanggilan terhadap tersangka untuk menghadiri persidangan. Pada persidangan, hakim selalu membuka sidang , dengan menyatakan "sidang dibuka dan terbuka untuk umum", 5 diteruskan dengan pemeriksaan identitas tersangka, dilanjutkan dengan pembacaan surat dakwaan oleh penuntut umum. Sebelum hakim meneruskan pemeriksaan hakim terlebih dahulu memberi kesempatan kepada terdakwa bersama penasihat hukumnya mengajukan eksepsi. Jika ternyata terdakwa atau penasihat hukum mengajukan eksepsi, hakim kemudian memberikan kesempatan kepada JPU untuk mengajukan bantahan. Setelah melalui proses sanggahan dan bantahan, hakim memberikan putusan sela yang isinya menolak atau mengabulkan eksepsi (pada umumnya dalam praktek eksepsi ditolak).

Pada aktivitas berikutnya, hakim memimpin persidangan untuk melakukan pemeriksaan baik terhadap terdakwa maupun alat-alat bukti yang diajukan di persidangan. Pemeriksaan ini sering juga disebut dengan tahap pembuktian. ${ }^{6}$ Pada tahap ini, hakim pertama-tama melakukan pemeriksaan terhadap saksi yang dipanggil masuk ke dalam persidangan secara bergantian. Hakim kemudian memeriksa indentitas saksi dan menanyakan apakah ada hubungan keluarga dengan terdakwa. Setelah saksi memberi keterangaan dilakukan pertanyaan silang (cross examination) yang dimulai dari Ketua Hakim Majelis diteruskan dengan Hakim Anggota, kemudian JPU dan giliran terakhir selalu jatuh pada Penasihat Hukum.

Disela-sela pemeriksaan saksi dimungkinkan dilakukan pemeriksaan terhadap barang-barang bukti yang terlebih dahulu diserahkan kepada hakim. Hakim memperlihatkan barang bukti kepada saksi bahwa apakah saksi mengetahui atau mengenal barang bukti tersebut. Pemeriksaan terhadap barang bukti guna mendukung keterangan saksi atau alat-alat bukti lainnya. Pemeriksaan pada tahap pembuktian ini diakhiri dengan pemeriksaan terhadap terdakwa.

Setelah proses pembuktian dilanjutkan dengan pengajuan requisitoir oleh penuntut umum kemudian ditanggapi dengan pengajuan pledoi dari terdakwa dan atau penasihat hukumnya. Atas pledoi ini jaksa penuntut umum menanggapinya dengan mengajukan replik, sebaliknya terdakwa atau penasihat hukumnya mengajukan duplik sebagai tanggapan terhadap replik. Setelah replik-duplik selesai, keseluruhan

5 Tidak semua persidangan, hakim menyatakan sidang dibuka dan terbuka untuk umum". Dalam perkara-perkara kesusilaan atau perkaranya melibatkan anak yang belum dewasa maka persidangan harus dilakukan dengan tertutup sehingga hakim tidak boleh menyatakan sidang dibuka dan terbuka untuk umum, melainkan hakim menyebutkan sidang dibuka dan tertutup untuk umum.

${ }^{6}$ Tahap pembuktian dinilai sebagai tahap terpenting di dalam persidangan karena melalui tahap inilah dapat ditemukan jawaban, apakah dakwaan jaksa penuntut umum dinyatakan terbutki atau tidak, demikian pula ditemukan jawaban tnetang ada tidaknya kekalahan terdakwa. (Lihat Rusli Muhammad, "Hukum Acara Pidana Kontemporer" (Yogyakarta : FH UII, 2006) him.130

7 Requisitoir diartikan sebagai kesimpulan jaksa penuntut umum dari hasil pemeriksaan dalam tahap pembúktian yang disertal dengan permohonan kepada hakim untuk menjatuhkan putusan kepada terdakwa. istilah yang digunakan oleh KUHAP adalah mengajukan tuntutan pidana, hal mana cukup membingungkan karena perkataan penuntutan telah diartikan seperti dalam Pasal 1 angka 7 KUHAP yang maknanya beda dengan yang digunakan ini, berarti ada satu istilah yang bermakna ganda. 
proses pemeriksaan diakhiri dengan pengambilan keputusan akhir oleh hakim. Dengan dijatuhkannya putusan kepada terdakwa berarti bekerjanya hakim berakhir dan untuk selanjutnya petugas Lembaga Pemasyarakatan mengambil alih tugas untuk melaksanakan pembinaan kepada terpidana. Petugas LP sekalipun juga termasuk aparatur hukum, namun dalam tulisan ini tidak:mendapat perhatian.

\section{Bentuk-bentuk Kekerasan Aparat Hukum}

Bekerjanya sistem peradilan pidana adalah suatu bentuk nyata dari mekanisme kontrol sosial yang terbentuk khusus dalam menghadapi pelaku kejahatan. Kejahatan timbul dari perilaku menyimpang yang dilakukan oleh mereka yang tingkat penghargaannya terhadap hukum sangat rendah, nilai kemanusiaan diabaikan dan terkadang terjepit oleh kebutuhan yang sulit dipenuhinya. Kejahatan terkadang identik dengan kekerasan, paling tidak kejahatan, umumnya dilakukan dengan kekerasan sehingga memunculkan istilah "kejahatan dengan kekerasan."

Kekerasan memang tidak dapat dipisahkan dengan kejahataan, namun kekerasan tidak selamanya muncul dari kejahatan, melainkan sebagai akibat dari pengendalian situasi tertentu atau sebagai akibat bekerjanya fungsi-fungsi yang melekat pada masing-masing aparatur penegak hukum. Namun, dalam pandangan Honderich, kadang-kadang kekerasan bisa digambarkan sebagai "ajakan terhadap rasa keadilan (sense of justice) dari mayoritas". Sehingga bila sense of justice ini dipaksakan oleh mayoritas masyarakat maka akan terjadi mala petaka bagi mereka yang minoritas. ${ }^{8}$ Sebaliknya, sense of justice dari minoritás yang tidak diperhatikan dan ditindas akan menjadi teror bagi kaum mayoritas.

Inti kekerasan, adalah pemaksisaan kehendak oleh satu orang terhadap orang lain, satu kelompok terhadap kelompok lain, atau satu institusi terhadap institusi lain. Dalam pengertian Sosiologi, oleh aktor yang satu terhadap aktor lainnya. Juga dalam hal manifestasi, kekerasan bisa bersifat fisik sekaligus simbolis. Sebuah amukan massa pada waktu kampanye dapat disebut kekerasan fisik sedang kooptasi terhadap sebuah partai politik dapat dipahami sebagai ujud kekeran simbolik. ${ }^{9}$

Secara teoritik menurut Mulyana $W$ Kusumah ada 4 (empat) kategori yang mencakup hampir semua pola-pola kekerasan yakni: ${ }^{10}$

\section{Kekerasan legal}

Banyak tindakan-tindakan kekerasan yang didukung oleh hukum. Seperti; seorang anggota tentara memperoleh ganjaran sebagai pahlawan atas intensitas perilaku kerasnya dalam rangka menjalankan tugas dan sportsport agresif tertentu contoh; tinju, serta tindakan tertenu untuk mempertahankan diri.

2. Kekerasan yang secara sosial memperoleh sanksi.

Semua faktor penting dalam menganalisis kekerasan adalah tingkat dukungan terhadapnya' atau sanksi sosial . Misalnya, tindakan kekerasan suami atas penzina akan memperoleh dukungan sosial.

${ }^{8}$ Honderich, Dalam Busyro Muqoddas dkk (editor) "Kekerasan Dalam Politik Yang Over Akting" (Yogyakarta : LKBH Ull 1998.) him. 87.

${ }^{9}$ Busyro Muqoddas dkk (editor) ibid hal xl.

10 Mulyana W Kusumah, Aneka:Permasalahan dalam Ruang Lingkup Kriminologi, (Bandung: Alumni, 1981), hlm. 15-16. 
3. Kekerasan rasional.

Beberapa tindakan kekerasan yang tidak legal akan tetapi tidak ada sanksi sosialnya adalah kejahatan yang dipandang rasional dalam konteks kejahatan. Misalnya: pembunuhan dalam rangka suatu kejahatan terorganisir.

4. "Illegal, nonsaanctioned, irrational violence" yakni kejahatan yang tidak berperasaan, yang terjadi tanpa adanya provokasi terlebih dahulu tanpa memperlihatkan motivasi tertentu dan pada umumnya korban tidak dikenal (dalam pembunuhan; oleh pembunuhnya).

Aparat hukum sebagai komponen terpenting dalam upaya penegakan hukum, terkadang terjebak oleh situasi yang memaksa harus bermain dengan berbagai bentuk kekerasan. Demonstrasi dan unjuk rasa yang dilakukan secara anarkis adalah bentuk situasi yang memaksa aparat kepolisiaan melakukan tindakan kekerasan. Sikap penolakan yang ditunjukkan oleh pelaku kejahatan serta sikap emosional aparat adalah juga menjadi faktor-faktor pemicu menimbulkan tindakan kekerasan.

Ada dua bentuk kekerasan yang dilakukan oleh aparat. Pertama, bersifat kolektif. Bentuk kekerasan ini adalah kekerasan yang dilakukan oleh aparat hukum secara bersama-sama dalam menghadapi suatu peristiwa demonstrasiyang terorganisir dan menjunus pada perbuatan anarkis. Aparat dalam menghadapi situasi demikian tidak jarang memilih tindakan kekerasan karena dengan tindakan kekerasan itulah dapat meredakan situasi menjadi pulih kembali. Bentuk kekerasan yang dilakukan misalnya dengan melakukan penyemprotan gas air mata atau dengan melakukan gerakan fisik dengan: bantuan alat-alat pelindung mendesak para demonstran agar membubarkan diri. Dalam situasi yang sulit dikendalikan dan berdampak kenugian yang lebih luas, aparat tidak segan-segan melakukan tindakan pemukulan dengan tongkat kayu, bahkan dengan menggunakan senjata yang beresiko jatuhnya korban.

Bentuk kekerasan yang bersifat kolektif lainnya, adalah ketika berhadapan atau berurusan dengan kriminal yang terorganisir. Pemburuan dan penangkapan terhadap pelaku kejahatan yang terorganisir, pihak aparat hukum tidak sendirian melainkan secara kolektif dengan melibatkan beberapa personil kepolisian. Aksi mereka selalu dihadapkan pada pilihan tindakan kekerasan sebagai imbangan atas perbuatan dan keberadaan para pelaku kejahatan itu sendiri. Bentuk kekerasan yang sifatnya kolektif ini dapat dicontohkan pada pemburuan dan penangkapan anggota komplotan teroris Nordin M Top yang barubaru ini dilakukan di Wonosobo. Tindakan kekerasan itu dilakukan pertama-tama dengan melemparkan bom ke rumah tempat persembunyian para pelaku, berkali-kali bom ini diledakkan untuk menakut-nakuti pelaku agar menyerahkan diri, kemudian diikuti dengan penggerebekan yang diwarnai dengan tembakan-tembakan untuk melumpuhkan para pelaku.

Kedua, bersifat individual, yakni tindakan kekerasan yang dilakukan oleh aparat terhadap pelaku kejahatan yang dilakukan oleh orang perseorangan. Bentuk kekerasan ini pada umumnya dilakukan oleh aparat hukum yang tidak diorganisir, namun terkadang dilakukan secara rahasia oieh seorang atau beberapa aparat penegak hukum. Bentuk kekerasan yang dilakukan oleh aparat hukum terhadap pelaku kejahatan orang perseorangan berbeda dengan kekerasan yang dilakukan terhadap 
kejahatan terorganisir sebagaimana tersebut di atas. Bentuk kekerasannya, aparat hukum jarang sekali menggunakan senjata dalam menghadapi pelaku, kecuali jika pelakunya melarikan diri ketika dilakukan penangkapan.

Jenis kekerasan bersifat individual ini, terjadi pada saat dilakukan pemeriksaan di kantor kepolisian, yakni ketika penyidik meminta keterangan kepada pelaku tentang perbuatan yang disangkakan kepadanya. Kekerasan ini timbul karena kesulitan memperoleh keterangan atau pengakuan dari tersangka. Seperti dikemukakan oleh Mirjan Damaska bahwa : Khususnya dalam kejahatan besar, apabila tersangka tidak mau secara sukarela mengakui perbuatannya atau kesalahannya, dan bukti yang dikumpulkan menimbulkan dugaan kuat akan kesalahannya, maka petugas pemeriksa akan memperpanjang penderitaan tersangka melalui cara penyiksaan (torture) sampai diperoleh pengakuannya."!

Berdasarkan pengalaman yang terjadi, aparat hukum melakukan kekerasan yakni dengan penyiksaan fisik, misalnya menidurkan tersangka di lantai yang kasar, kemudian meletakkan kakinya yang bersepatu besar di atas pelipis tersangka sambil digoyang-goyang sehingga pelipis bagian bawah bergesekan dengan tembok yang kasar. Terkadang pula dilakukan pemukulan dengan menggunakan-tängan atau:senjata laras panjang sehinga membuat badan pelaku menjadi memar. Atau dapat pula dilakukan dengan menggunakan puntung rokok yang masih menyala disulutkan pada bagian muka atau tangan sehinga pelaku merasa kesakitan. Tindakan kekerasan aparat ini, dapat terjadi karena dipicu oleh sikap terșangka yang tidak mau mengakui perbuatan yang disangkakan kepadanya, namun tidak jarang pula terjadi disebabkan karena luapan emosi aparat dalam menyikapi perbuatan tersangka yang selalu merepotkannya.

Bentuk-bentuk kekerasan tersebut di atas adalah lebih diarahkan kepada pisik, sehingga dapat pula dikategorikan sebagai kekerasan pisik. Dalam praktek terutama praktek peradilaan, ternyata tidak saja terjadi kekerasan pisik melainkan dapat pula terjadi bentuk kekerasan lainnya yakni kekerasan psikis. Bentuk kekerasan ini, yang dikehendaki bukannya mendatangkan rasa sakit pada bagian tubuh, melainkan lebih diarahkan pada timbulnya rasa takut, sehingga dengan rasa takut itu dapat melakukan , berbuat atau mengakui suatu perbuatan tertentu.

Bekerjanya sistem peradilan pidana dapat menimbulkan bentuk kekerasan psikis baik pada tingkat penyidikan, penuntutan maupun pada tingkat pemeriksaan di sidang pengadilan. Pada tingkat penyidikan; kekerasan psikis dapat terjadi ketika pihak penyidik melakukan interogasi kepada pelaku kejahatan dengan mengajukan pertanyaanpertanyaan yang jawabannya sangat memberatkan, namun penyidik memberikan peringatan bahiwa kalau tidak dijawab sebagaimana yang diinginkan àkan berakibat fatal bagi dirinya sebab dapat menyebabkan penahanan bertambah lama dan hukumannya pun akan diperberat. Ancaman yang demikian menyebabkan timbulnyaa rasa takut dan keterpäksaán untuk memberikan suatu jawaban atau suatu pengakuan atas perbuatan yang dilakukannya.

- Hal yang sama dapat pula terjadi di tingkat kejaksaan, bahwa untuk memberikan keyakinan atas perbuatan tersangka,

11 Mirjan Damaska, dalam Ràmii 'Etmasasmita, "Bunga rampai Hukum Acara Pidana" (Bandung : Penerbit Binacipta $a_{j}$ 1983) him. 3 . 
terkadang Jaksa Penuntut Umum menawarkan agar di persidangan mengakui saja perbuatannya karena kalau tidak akan dituntut pidana yang lebih berat. Permintaan JPU demikian tentu menakutkan dan menjadi pemikiran yang berat baginya, sebab jika tidak mengakui akan mendapat tuntutan pidana yang berat sementara jika diakui berarti membongkar rahasia yang selama ini ditutup rapat.

Pada tingkat pengadilan, kekerasan psikis dapat pula dialami oleh terdakwa. Seperti diketahui bahwa bentuk dan suasana pengadilan ditata sedemikian rupa sehingga menampilkan suasana yang berwibawa, namun bagi. terdakwa suasana demikian adalah menakutkan dan terkesan angker karena berhadapan dan dikelilingi oleh orangorang yang berseragam hitam-hitam. Pakaian toga yang panjang dan berwama hitam yang selalu dipakai oleh hakim, penuntutumum dan penasihat hukum dalam setiap persidangan, bagi terdakwa adalah pemandangan yang menyeramkan dan menakutkan seolah-olah mereka bersamasama dengan makhluk lain yang akan menerkamnya. Kondisi inilah yang dirasakan sangat menyiksa batin lebih-lebih jika para hakim atau penuntut umum mengajukan pertanyaan yang sedikit membentaknya, hati mereka tambah nunyam.

\section{Pembenaran Kekerasan Aparat Hukum}

Kekerasan yang sudah dimulai dan ditunjukkan oleh anak keturunan pertama NabiAdam, bukan rahasia lagi, kini semakin fenomenal. Bahkan kita tidak mengira jika sekarang ini kekerasan telah menjadi sesuatu yang umum. Di mana-mana terjadi kekerasan, tidak ada lagi ruang yang kosong dengan kekerasan; bahkan di tempat yang suci dan terhormat sekalipun terjadi kekerasan, itulah yang pernah ditunjukkan oleh sebagian anggota dewan di ruang sidang DPR yang terhormat itu.

Bahwasanya penggunaan kekerasan dalam menyelesaikan persoalan senantiasa meninggalkan dan berdampak tidak saja pada kerugian materiil tetapi juga mendatangkan penderitaan fisik maupun psikis pada orang lain. Itulah sebabnya terdapat kalangan yang menolak kekerasan dipakai sebagai cara dalam memecahkan persoalan dan berusaha menggantikannya dengan cara-cara yang lebih manusiawi. Namun demikian, tetap saja ada pihak-pihak yang menggunakan kekerasan sebagai suatu alternatif pemecahan persoalan di samping alternatif lainnya.

Tentu penggunaan kekerasan oieh aparat hukum dalam menyelesaikan berbagai persoalan yang dihadapi bukan tanpa alasan, melainkan didasarkan selain pada pengalaman profesionalisme juga didasarkan pada ajaran-ajaran yang berkembang dalam sistem pèradilan pidana, bahkan juga didasarkan pada aturan-aturan hukum baik yang ada di dalam peraturan perundang-undangan maupun di dalam piagam PBB. Alasan-alasan pembenar inilah yang akan diuraikan pada bagian berikut ini.

Salah satu aparat hukum yang tidak luput dari tindakan kekerasan adalah aparat kepolisian. Aparat kepolisian yang diberi tugas pokok memberikan keamanan dan ketertiban masyarakat; menegakkan hukum dan memberikan perliñdüngān-dan pelayanan kepada masyarakat, nampáknya sudah terbiasa dengan kekerasan, baik kekerasan itu muncul dari diri mereka sendiri ataupun dari para pelaku kejahatan.

Pengalaman profesionalisme aparat hukum, khususnya aparat kepolisian menjadi alasan pembenar di dalam melakukan tindakan kekerasan. Aparat kepolisan dalam menghadapi berbagai 
kasus-kasus kriminal, terbiasa menyelesaikannya dengan mengikuti cara-cara atau praktek-praktek yang pernah dilakukan sebelumnya. Pengalaman ini diikutinya karena dengan cara itu, terbukti dapat memberikan hasil yang memuaskan, paling tidak mempercepat penyelesaian perkara yang ditanganinya. Hal ini dapat dilukiskan ketika seseorang tersangka yang diperiksa karena disangka melakukan suatu perbuatan pidana tertentu, jika pemeriksaan dilakukan tanpa kekerasan, jawabannya berbelit-belit dan terkadang sulit mengakui perbuatannya, namun jika dengan melakukan sedikit kekerasan, pengakuan itu pun segera meluncur dari mulutnya.

Satu pengalaman seorang penyidik yang sempat disampaikan pada penulis bahwa setelah ia menerima laporan dari korban kejahatan, segera melakukan penangkapan dan diteruskan dengan pemeriksaan. Pemeriksaan dilakukan tengah malam tidak lama setelah dilakukan penangkapan yang dilakukan pada malam itu juga. Pada saat pelaku dimintai pengakuannya atas perbuatan yang disangkakan padanya, semula tidak mau mengakui, namun setelah terdakwa diperintahkan tidur di lantai kemudian kepalanya sedikit ditindis dengan kayu, tidak lebih dari satu jam, tersangka sudah mengakui perbuatan pidana yang ia lakukan.

Tindakan kekerasan yang menjadi pilihan aparât hukum tidak lepas pula dengan ajaran-ajaran yang berkembang di dalam sistem peradilan pidana. Prinsip inquisitoir dan accusatoir adalah ajaran yang berkembang di dalam peradilan pidana sekalipun dalam implementasinya di berbagai negara berbeda-beda. Prinsip inquisitoir, mengajarkan bahwa pemeriksaan dilakukan secara tertutup dan tersangka ditempatkan sebagai obyek pemeriksaan. Prinsip ini sangat berbeda dengan prinsip accusatoir, di mana pemeriksaan dilakukan dengan terbuka dan tersangka/terdakwa ditempatkan sebagai subyek pemeriksaan.

Jika mencermati ajäran-ajaran inquisitoir, terlihatadanya pembatasan terhadap hak-hak asasi manusia, bahkan dimungkinkan terjadinya pelanggaran terhadap hak-hak asasi tersebut. Pembatasan dan pelanggaran terhadap hak-hak asasi dapat dibenarkan sepanjang tindakan tersebut dilakukan dalam rangka keberhasilan upaya penanggulangan kejahatan. Oleh karena itu, tindakan kekerasan yang mewarnai bekerjanya sistem peradilan pidana merupakan cerminan ajaran pemeriksaan dengan sistem inquisitor. Adalah sangat berbeda jika menggunakan ajaran pemeriksaan dengan prinsip accusatoiryang sangat menjunjung hak-hak asasi manusia . Tindakan keke-rasan menurut ajaran ini harus dihindari, tindakan harus didasarkan pada aturan-aturan yang ditetapkan sebelumnya.

Sejalan dengan prinsip tersebut di atas, dikenal pula beberapa model dalam sistem peradilan pidana, di antaranya adalah Crime Control Model. ${ }^{12}$ Model ini adalah suatu sistem nilai yang lebih memprioritaskan upaya penanggulangan kejahatan secara maksimal. Ideologi/dasar pemikirannya adalah efisiensi (prosedural dan biaya) dan hasil yang maksimal. Model ini lebih memberikan porsi kewenangan yang lebih besar pada penguasa sehingga terjadi

12 Herbert Packer mengemukakan bahwa dua teori keadilan yang berlaku dalam lingkup "the criminal justice system", Pertama "Crime Control Model" dan kedua, adalah "Due Process Model". Lihat Herbert Packer , The Limits of The Criminal Sanction (California : Standford University Press, 1968) hlm 153. Dapat pula dilihat dalam Gerge F. Cole, "Criminal Justice: Law and Politics" (Nort Scituate, Massiachusetts: Duxbury Press. 1978) hlm 51: 
penonjolan kekuasaan. Dampaknya adanya batasan hak-hak pada pelaku. Mekanisme kerjanya lebih menonjolkan kekuasaan sehingga ada peluang terjadi pelanggaran hak-hak asasi manusia. Semua hal yang mencampuri jalannya proses tidak diperkenankan, hal demikian dianggap sebagai rintangan yang mengganggu jalannya peradilan yang efisien. Misalnya; polisi menjalankan tugas tidak boleh ada orang yang mengganggu pekerjaannya, termasuk tersangka yang berbelit-belit memberikan keterangan, jika perlu digunakan kekerasan untuk memperlancar jalannya proses.

Dengan berpijak pada ajaran crime control model, menjadi dasar pembenar bagi aparat hukum ketika suatu saat menggunakan tindakan paksa berupa kekerasan dalam upayanya memberantas kejahatan sekalipun harus mengenyampingkan peraturan hukum yang ada. Sekalipun tindakan kekerasan dibenarkan, namun untuk melakukannya bukan untuk berbagai kepentingan, melainkan tindakan kekerasan tersebut semata-mata dilakukan untuk kepentingan efisiensi dan hasil yang maksimal dalam upaya pengendalian kejahatan.

Berbagai pengalaman telah dilakukan oleh aparat hukum dalam memberantas kejahatan dengan mengedepankan tindakan kekerasan . Belum hilang dari ingatan bahwa beberapa tahun yang lalu di Yogyakarta dilakukan penangkapan dengan paksa terhadap para 'gali' bahkan terdapat di antara mereka yang harus di eksekusi tembak mati di tempat, tanpa melalui tahapan-tahapan prosedur sebagaimana yang ditentukan oleh hukum, mereka tidak dibuatkan berita acara pemeriksaan, tidak dituntut ke' pengadilan dan tidak pula disidang di pengadilan pidana, melainkan langsung dibrondong senjata hingga mereka tewas. Demikian pula terjadi di jawa Timur dilakukan pembersihan melalui penangkapan paksa terhadap mereka yang dikenal dengan isitlah 'bromocorah', kebanyakan mereka di eksekusi tanpa melalui jalur hukum yang telah ada.

Police hazard ${ }^{13}$ juga menjadi sasaran yang mendapat perhatian, namun tindakan ini memerlukan pensyaratan sebagai landasan dan sekaligus menjadi alasan pembenaran. Secara teoritik beberapa persyaratan yang harus dipenuhi di dalam melakukan tindakan terhadap police hazard yaitu, pertama: harus didasarkan pada asas proporsionalitas. Asas ini menghendaki agar tindakan yang dilakukan itu harus memperhatikan keseimbangan antara tujuan dan sarana yang hendak dicapai atau keseimbangan antara tindakan yang dilakukan dengan perbuatan yang terjadi. Dengan demikian polisi misalnya, jika memang mengharuskan melakukan penembakan harus melihat terlebih dahulu seberat apa perbuatan yang dilakukan itu. Apakah penembakan yang dilakukan itu sudah seimbang dengan perbuatan orang yang menjadi sasaran penembakan: Jika tidak, berarti tidak proporsional.

Kedua, adanya pembelaan darurat terhadap masyarakat (Publicke Noodweer). Syarat ini menghendaki bahwa tindakan yang dilakukan untuk menangkal atau membasmi police hazard adalah dilakukan dalam rangka pembelaan terhadap masyarakat, dan masyarakat sendiri mengharapkan dan memberi dukungan

${ }^{13}$ Police hazard adalah suatu situasi, keadaan yang menyebabkan pihak kepolisian mengambil tindakan yang sifatnya prefentif agar tidak berkembang menjadi kejahatan: (Dapat dibaca dalam bahan kuliah Prof. Muladi tentang Sistem Peradilan Pidana pada S-2 FH UNDIP thn 1987. 
Aparat Hukum dan Pembenaran Kekerasan; Rusli Muhammad

terhadap tindakan darurat itu. Oleh karena itu, jika polisi melakukan tindakan terhadap police hazard hendaknya dapat diteliti betul, bahwa seberapa jauh tindakannya itu mendapat dukungan dari masyarakat, sehingga tidak terkesan asal ngaur bertindak.dan Ketiga : Adanya Public Partisipation. Yaitu bahwa segala yang dilakukàn oleh Polri itu harus didukung dan adanya keterlibatan langsung masyarakat yang tumbuh dari. bawah. Partisipasi masyarakat ini mengharuskan poliși dapat bekerja sama dalam melakukan tindakan terhadap segala bentuk-bentuk kerawanan sosial yang menjadi bagian dari police hazard.

Selain alasan-alasan pembenaran kekerasan oleh aparat hukum tersebut, alasan pembenar dapat pula bersumber dari ketentuan hukum formal. Seperti tercantum dalam KUHAP yang memberi kewenagan kepáda penyidik untuk mengadakan tindakan lain menurut hukum yang bertanggung jawab (pasal 5 ayat (1) angka 4). Pasal ini sebenamya tidak menyebutkan secara jelas tentang kekerasan, akan tetapi kekerasan tersebut dapat dimaksudkan sebagai bentuk dari perkataan "tindakan lain". Dengan demikian, kekerasan dapat dilakukan asalkan atas dasar pertimbangan yang layak dan keadaan memaksa, misalnya, perbuatan seseorang penyidik yang dengan terpaksa telah melepaskan beberapa tembakan peringatan yang ditujukan kepada sejumlah besar orang yang berusaha memberikan perlawanan terhadap dirinya, atau pada waktu melakukan suatu penangkapan terhadap seseorang yang ternyata melarikan diri. ${ }^{14}$

Selain itu dalam Pasal 2 ayat (4) Bab VII Piagam PBB, membolehkan penggunaan kekerasan berkaitan dengan adanya ancaman atau tekanan menghadang integritas teritorial. Demikian pula disebutkan dalam Pasal 51 bahwa penggunaan kekerasan secaara.individual dan kolektif merupakan hak atas pembelaan diri (self defence). ${ }^{15}$

\section{Penutup}

Sebelum mengakhiri tulisan ini dapat ditarik beberapa kesimpulan sebagai berikut:

1. Bahwa Aparatur hukum adalah salah satu pilar yang terpenting dalam sebuah negara hukum karena ditangannyalah citra sebuah negara hukum dipertaruhkan. Ketika segenap aparatur hukum dalam segala aktivitasnya menjadi teladan dalam penegakan hukum, maka eksistensi dari negara hukum terwujud, sebaliknya jika para penegak hukum dalam menjalankan segala aktivitasnya tidak lagi sebagai panutan, maka eksistensi dari sebuah negara hukum menjadi sirna dan yang tersisa tinggal simbol belaka.

2. Bahwa bekerjanya aparátur hukum (polisi, jaksa dan hakim), yang diawali tindakan penyelidikan/penyidikan, penuntutan dan pemeriksaan pengadilan, sekalipun secara kelembagaan terpisah dengan undang-unidangnya sendiri, namun satu sama'lainnya tidak terpisahkan, tetap terkait dan terikat dalam satu sistem yang dikenal dengan nama 'sistem peradilan pidana'.

3. Bahwa bentuk-bentuk kekerasan yang dilakukan oleh aparat hukum dapat bersifat individu dan kolektif. Dalam bentuk lain kekerasan itu dapat berupa kekerasan fisik dan kekerasan psikis.

${ }^{14}$ P.A.F Lamintang lbid , hlm 64

"15 Dikutif dari bagian tulisan Jäwahir Thontowi dalam Kolom Analisis Härian Kedaulatan Rakyat, terbit selasa 9 Mei 2006. 
Kesemuanya terjadi disebabkan berbagai alasan, ada yang dipicu oleh situasi anarkis, ada yang dipicu oleh sikap dan perilaku pelaku kejahatan dan ada pula karena akibat dari tingkat emosional aparatur itu sendiri .

4. Bahwa alasan pembenar terhadap tindakan kekerasan yang dilakukan oleh aparat hukum adalah pengalaman profesionalisme aparat hukum itu sendiri, ajaran-ajaran pemeriksaan dengan sistem inquisitoir, ajaran-ajaran penanggulangan kejahatan dengan crime control model serta peraturanperaturan hukum formal yang berlaku.

\section{Daftar Pustaka}

Cole, George F.1978. "Criminal Justice: Law and Politics", Nort Scituate, Massachusetts : Duxbury Press.

Reksodiputro,Mardjono,1994. Kriminologi dan Sistem Peradilan Pidana Jakarta : Penerbit Lembaga Kriminologi UI.

Muladi, 1995. "Kapita Selekta Sistem Peradilan Pidana." Semarang : Penerbit Badan Penerbit Universitas Diponegoro.

Kusumah,Mulyana W,1981. Aneka Permasalahan dalam Ruang Lingkup Kriminologi, Bandung:Alumni.
Muqoddas, Busyro dkk (editor), 1998, "Kekerasan Dalam Politik Yang Over Akting", Yogyakarta: Penerbit LKBH Ull.

Packer, Herbert L. 1968. "The Limits of The Criminal Sanction. California : Standford University Press.

PAF. Lamintang,1984. "Kitab UndangUndang Hukum Acara Pidana Dengan Pembahasan Secara Yuridis Menurut Yurisprudensi dan IImu Pengetahuan Hukum Pidana. Bandung: Penerbit Sinar Baru.

Atmasasmita,Romli,1983. “Bunga rampai Hukum Acara Pidana" Bandung : Penerbit Binacipta.

Muhammad,Rusli ,2005. Modul Hukum Acara Pidana.Yogyakarta : Penerbit FHUIl. ,2006. Hukum Acara Pidana Kontemporer. Yogyakarta : FHUII.

Soekanto,Soerjono dan Mustafa Abdullah,1980. Sosiologi Hukum dalam Masyarakat. Jakarta: Penerbit Rajawali. 